\title{
Fossilized pollination droplet in a new seed genus from the Middle Triassic of Nidpur, India
}

\author{
Nupur Bhowmik and Shabnam Parveen \\ Acta Palaeontologica Polonica 59 (2), 2014: 491-503 doi: http://dx.doi.org/10.4202/app.2012.0026
}

The present article reports a fossilized pollination droplet at the micropylar orifice in a compressed seed Gopadispermum papillatus gen. et sp. nov. from the Middle Triassic beds of Nidpur, Madhya Pradesh, India. The shapeless droplet forming a convexity above the micropylar orifice is comprised of a resinous crystalline substance. Entrapped within the droplet are a few saccate pollen grains. The seeds are small, oblong to widely elliptical in shape, about $3 \mathrm{~mm}$ long and generally $2 \mathrm{~mm}$ broad. The micropylar end shows a short straight beak-like micropyle often extended beyond a persistently adhering wrinkled tissue lying outside the seed coat. The seed is composed of four membranes excluding the adherent tissue. They are the outer and inner cuticles of integument, the nucellar cuticle distally modified to form a dark collar-like pollen chamber and the innermost megaspore membrane. Cuticles of the tissue adhering to seed coat are different from seed coat cuticles. The pollen grains inside the pollen chamber are frequently clumped together forming a pollen mass. Individual pollen grains appear spheroidal to ellipsoidal in shape and are saccate. This is the first report of the preservation of a pollination droplet in a compressed seed specimen from the Nidpur Triassic beds. Preservation of the droplet can be attributed to its supposed resinous constitution and the entrapped organic contents (pollen grains). Occurrence of clumped pollen grains inside the pollen chamber also indicated possibility of fluid feeding, pollinivory, and insect pollination in the seeds.

Key words: Plantae, Ginkgoopsida, Rugaspermum, pollen, seed, pollination, micropyle, compression, Triassic, India.

Nupur Bhowmik [b nupur27@ rediffmail.com] and Shabnam Parveen [shabnam d.phil@yahoo.co.in], Department of Botany, University of Allahabad, Allahabad 211002. Uttar Pradesh, India.

This is an open-access article distributed under the terms of the Creative Commons Attribution License (for details please see creativecommons.org), which permits unrestricted use, distribution, and reproduction in any medium, provided the original author and source are credited. 
Far Full text $(946.1 \mathrm{kB})$ ।

FoF Supplementary file $(65.9 \mathrm{kB})$ 